\title{
The Republic of Singapore Navy: From Humble Beginnings to a Balanced Fleet ${ }^{1}$
}

\section{Joshua Ho}

\begin{abstract}
L'histoire de la Marine de la République de Singapour est inextricablement liée à l'histoire de la Marine royale malaisienne de l'époque, avant indépendance, où les deux pays étaient administrés comme une seule entité par le gouvernement colonial britannique. La Réserve navale volontaire des Établissements des détroits était la base pour les deux marines et a été formée avant la seconde guerre mondiale avec un seul navire. Après la seconde guerre, la force est devenue la Force navale malienne et a été équipée de cinq navires pour faire face à la situation d'urgence. Cette force a ensuite été transférée à la Malaisie péninsulaire nouvellement indépendante et rebaptisée Marine royale malienne avec 10 navires qui a de nouveau été rebaptisée la Marine royale malaisienne en Septembre 1963 suite à la formation de la Malaisie. Le 9 Août 1965, Singapour a quitté la Malaisie pour former une nation indépendante et souveraine et la Force navale volontaire de Singapour a été formée avec deux navires, force qui est devenu l'ancêtre de la Marine de la République de Singapour.
\end{abstract}

\section{British Origins}

The Republic of Singapore Navy (RSN) traces its origins to the Royal Navy in the 1930s with only two patrol craft. The Straits Settlements Royal Navy Volunteer Reserve was established on 20 April 1934 and in 1941 became the Singaporean division of the Malayan Volunteer Reserve during the Second World War. In 1948, the Malayan Naval Force (MNF) was raised by the Singaporean government and was later granted the title of Royal Malayan Navy in 1952 in recognition of its services in action during the Malayan Emergency.

On 16 September 1963 Singapore was admitted as a state of Malaysia under the terms of confederation and the Royal Malayan Navy was renamed the Royal Malaysian Navy (RMN). The Singapore division of the Malayan Royal Navy Volunteer Reserve

1 This article has adapted material from the first two chapters of: Republic of Singapore Navy, Onwards and Upwards: Celebrating 40 years of the Navy (Singapore: SNP International Publishing, 2007).

The Northern Mariner/Le marin du nord XXIV, Nos. 3 \& 4 (Jul. \& Oct. 2014), 124-134 Canadian Military History 23, Nos. 3 \& 4 (Summer \& Autumn 2014), 124-134 
was formally transferred from the command of the Royal Navy to the RMN on 22 September 1963, becoming the Singapore Volunteer Force (SVF), and on 22 January 1966 the Singapore Naval Volunteer Force (SNVF). On 9 August 1965 Singapore seceded from Malaysia to form an independent and sovereign nation within the Commonwealth of Nations. Like the young nation of Singapore, the Singapore Navy was born in tumultuous times. The separation from Malaysia had just taken place. Many did not give Singapore much chance of surviving, let alone prospering. However, the government and the people remained undaunted and resolute. They were determined for Singapore to succeed and to protect the independence that was thrust upon them. With memories of Second World War and Konfrontasi (the Indonesian Confrontation) fresh in their minds, securing the fledgling nation's sovereignty was never more pressing. Security was of utmost priority. Yet, there was hardly any defence force to speak of. All Singapore had at independence were two army battalions and two wooden ships. There was no air force.

\section{Building a Defence Force}

Singapore had to build its defence force from scratch. It was a Herculean task, made even tougher when the British announced in January 1968 that by the end of 1971 they would pull out of their military bases east of the Suez. The hope that the British would stay on to give Singapore time to build up a credible defence force was shattered. The nation had to defend itself on land, in the air and at sea, and had to build up its defence forces quickly.

With Singapore completely surrounded by water, the need for a navy was clear. Aside from securing its sovereignty, the Republic also had to combat threats posed by sea robbers operating in the waters around Singapore. The SNVF became responsible for the defence of the sea. With only a handful of volunteers and two wooden ships, the Republic of Singapore Ship (RSS) Panglima and RSS Bedok, it was a tall order. As the lightly-armed ships had a top speed of 15 knots, they were only suited for constabulary duties, and while their presence was felt in the Singapore Strait they would have been hard-pressed to pursue sea robbers in high-speed boats, let alone stand a chance against warships of that era.

Plans were then drawn up to develop a navy that would better safeguard Singapore's waters. Such a navy needed more capable ships, needed to 'regularize' its volunteer force, and needed to recruit and train more men and women.

In June 1968, a S\$30 million contract for the construction of six patrol craft was signed. These 110-foot craft were touted as Singapore's 'Super Boats' and were set to be the nascent navy's most well-armed patrol craft, capable of speeds greater than 30 knots. They would form the backbone of the navy, playing a key role in maintaining security, deterring and preventing smuggling, sea robberies and the infiltration of illegal immigrants.

\section{The Pioneers and Early Years}

To build a professional navy, sailors had to be well-trained, disciplined and 
leaders in their own right. But first, the navy had to recruit sailors to fill its ranks. Sailors were drawn from all walks of life. So long as they were between $171 \frac{1}{2}$ and 23 years old, possessed at least a Secondary Two certificate, were physically fit and had good eyesight, they fit the bill. By early 1969, the first batch of 160 naval recruits comprising 20 electricians, 20 engineers and 120 seamen had begun formal naval training. Instructors from the Royal New Zealand Navy provided training because Singapore did not have any naval experts. While training for seamen and naval technicians was conducted locally, midshipmen were sent abroad to Britain, Australia, New Zealand and Canada to learn from established navies and to gain operational exposure.

The pioneers had much to look forward to. A new naval base was being constructed on Pulau Brani. Uniquely navy beige uniforms with blue berets replaced the 'Temasek Greens'. Most importantly, the first patrol craft (PC), RSS Independence, was commissioned in December 1970. With all six PCs commissioned by January 1972, the Navy was able to sustain patrols in the Singapore Strait and fill a small part of the vacuum left by the British withdrawal in 1971. While beginning operations gave the navy its first real taste of managing seaward security, moving to Brani finally gave the navy a home it could truly call its own. In January 1974, Brani Naval Base was officially opened by then Prime Minister Lee Kuan Yew. Ships could now be berthed next to the operational headquarters, along with logistics elements such as the workshops and the Naval Technical Training School (NTTS). Previously, navy ships were moored offshore, while the headquarters was located ashore on Pulau Blakang Mati (now called Sentosa Island).

As the 'heartware' of the navy grew, so did its hardware. The six PCs, designed for constabulary duties, lacked reach and a lethal punch. In 1968, a suitable strike craft was sought and was found in the missile gunboats (MGBs) built by the Lurssen Shipyard in Germany. The acquisition of the MGBs was a watershed: small but nimble, the MGBs were equipped with the latest radars, electronics and missiles, packing an arsenal that could sink warships many times their size, and marked the navy's first foray into maritime warfare. In January 1975, the first three MGBs were commissioned, followed by the remaining three a year later, in February 1976. With the MGBs, the Singapore Navy had become the first navy in the region to successfully fire an anti-ship missile, the Gabriel missile.

In building up the Singapore Army's core capabilities, there was a need to train overseas to overcome space constraints in Singapore. Overseas training provided the army more space to conduct realistic manoeuvre exercises, artillery live-firing, and to fully test its equipment and operating doctrines. The army needed to transport its heavy equipment to and from these overseas training areas. A squadron of Second World War County-class landing ship tanks (LSTs), bought at a token price of a dollar each from the United States, was entrusted to undertake this task. To provide the navy with a minesweeping capability, two old coastal minesweepers also were procured from the United States. These small ships sailed 13,000 km from San Francisco to Singapore - a journey of almost epic proportions for a tiny navy. 
With the introduction of more ships into the navy's order of battle, it needed the capability to do rudimentary underwater repair work. The Singapore Armed Forces Diving Centre was formed in 1971, comprising a small group of 16 divers. The Centre was renamed the Naval Diving Unit (NDU) in 1975, and in the 1980s started to move beyond a support role, to include combat diving and mine clearance operations. Naval divers were sent overseas for courses like the Basic Underwater Demolition, Explosive Ordnance Disposal (EOD) and the elite Sea Air Land (SEAL) course.

As the navy grew, a critical mass of officers was needed. Although ratings were already trained locally, officers continued to be trained overseas. Professional training in the navy reached a new milestone when the Midshipman School was formed in April 1974. This was long overdue as overseas training billets were insufficient to provide for enough officers for the navy. The Class of 1974 consisted of 12 regulars and 30 National Servicemen. This pioneer cohort of 42 midshipmen far exceeded the number trained overseas annually. Since its inception, hundreds of midshipmen have passed through Midshipman School to provide sterling service to the navy.

\section{The Navy in the Mid-1970s}

The navy rapidly moved out of a decade of infancy. Training schools for both ratings and midshipmen produced a steady stream of qualified personnel. Morale was high. Operationally, the navy kept up its tempo of daily patrols. When duty called during the M/V Laju hijack incident in 1974, the navy performed well and its four ships deployed for this operation effected a cordon around the Laju to prevent the terrorists from escaping. With the navy's coming of age, it was time to give it due recognition, and on 1 April 1975 the Singapore Maritime Command was renamed the Republic of Singapore Navy (RSN) and the future of the navy seemed bright. However, it was to undergo a severe test with the fall of Vietnam to the communists.

An influx of 8,408 'boat people' in 64 vessels arrived during May 1975. The navy was called upon to manage the mammoth task of providing the boat people with food and fuel, as well as repairing their vessels. Although the operation itself lasted only 13 days, the navy was tasked to continue these surveillance patrols right through the early 1980s, as such boats continued to trickle in. Operation THUNDERSTORM was a defining operational experience, but it was a huge drain on the fledgling navy. Everything outside of this operation was set aside and no one was spared. There was no time for training, maintenance or doctrine development. The protracted task of dealing with the influx of boat people marked the start of a difficult chapter in the navy's history, its future hanging in the balance.

Following Operation THUNDERSTORM, the navy was buffeted by a series of setbacks. The tempo of anti-illegal immigrant operations had to be sustained, but given the absence of a comprehensive shipping picture in the Singapore Straits, and that the navy could only deploy two ships on patrol each day, some of the many illegal immigrant boats slipped through. The navy also had problems with its missile firings as the Gabriel missile could not hit its targets. As a result, the operational utility of the navy beyond the Singapore Strait was in serious question due to its poor performance, and defence 
planners in the Ministry of Defence (MINDEF) gradually formed the view that there was only a very limited role for the navy. The RSN was in a dismal state and capability and doctrine development were in a hiatus. Facing an uphill task to establish its strategic role, higher headquarters could not see a role for the navy that could warrant improving its capabilities significantly. This sorry state of the navy as it entered the 1980s was a stark contrast to the 1970s. Morale was low.

However, the breakthrough came when the RSN started to examine from first principles why Singapore needed a navy. A look at Singapore's trade statistics showed that the trade dependency ratio was approximately 4:1, meaning that the economic wellbeing of Singapore depended critically on trade, most of which came by sea. From there, it became unmistakable that the protection of the sea lines of communication (SLOCs) was vital for sustaining Singapore's economic well-being. With the recognition that Singapore could be 'choked' to death by economic strangulation, the need for the navy to secure Singapore's SLOCs became a strategic mission of the RSN. By the early-1980s, with its mission refocused and its strategy redefined, the navy embarked on a process of revitalization and started to develop a balanced set of capabilities.

\section{Force Development Projects in the 1980s and 1990s}

The first acquisition after the soul-searching period was 12 coastal patrol craft (CPC). Designed and built locally, they were commissioned in October 1981 and proved significant in contributing to the revitalization of the navy. The CPCs helped to relieve the MGBs from the task of daily patrols and created the capacity within the rest of the navy to pick up where it had left off in the mid-1970s.

The MGBs also underwent an upgrade in the 1980s that saw the vessels being equipped with long-range, hard-hitting Harpoon missiles. Other systems introduced included an action information system (AIS) to track and display other vessels. Together with a secure digital communications and datalink upgrade, the MGBs were able to share a common tactical picture at sea and tremendously increased their capability to fight coherently as a force.

The navy then made plans for more diverse hardware like the mine countermeasure vessels (MCMVs) and the maritime patrol aircraft (MPA). It also received the go-ahead to build a squadron of six missile corvettes (MCVs). The MCVs were the first RSN ships designed to deal with the underwater threat posed by submarines. Armed with the latest weaponry, including anti-submarine torpedoes and Harpoon missiles, and equipped with the latest sensors, the MCVs put to sea within eight years of project approval.

In tandem with the hardware purchases, software had to be developed. Investment in the first-generation Tactical Training Centre (TTC) proved vital and enabled the navy to focus on tactical war-fighting and training. This was because on the MGBs it was difficult to provide any real tactical training, but rather only technical training at best, and there remained a lack of tactical doctrine.

The TTC provided the foundation for the navy to hone the tactical sense of its 
officers and provided a testing ground to refine the doctrine and tactical procedures that were being developed. It shaped the way the navy was going to fight and was instrumental in transforming it into a well-oiled fighting force, putting the RSN on a footing that brought up professional standards in a fundamental way and paved the way for more to come.

\section{Looking Back, Stepping Forward}

In retrospect, had it not been for the difficult times during Operation THUNDERSTORM, the navy could well have been content with just operating missile gunboats and might then have become the proverbial frog in the well, never imagining nor realizing the formidable capabilities of today's RSN.

The navy accepted from early on that it had to operate at a numerical disadvantage. Therefore, it became an early adopter of technology, networks and datalinks to overcome this problem. As the service with the smallest slice of the budget in the 1970s, it could not afford expensive off-the-shelf solutions. To develop costeffective solutions, it worked with the Defence Science Organisation (DSO), which was previously known as the MINDEF Electronics Test Centre, to devise indigenous capabilities to meet its unique requirements in areas ranging from electronic warfare (EW) to stealth and guided weapons.

Besides relying on technology, during hard times, it was the persistence of its people that made the difference. What kept the navy going in the difficult years of the 1970s was the uniting dedication of its people. The struggles in those initial years had made the leadership in the navy stronger, and they learnt to communicate across ranks to create openness and trust and manage expectations. Such was the spirit of the navy pioneers and the people who chose not to lose heart, that eventually the RSN regained a firm footing in the 1980s. From humble beginnings, the navy overcame daunting challenges, and with its mission clearly defined, the stage was set for its next phase of development.

\section{The Fighting Navy}

Today, the navy is able to carry out a wide range of operations. Aside from the ability to counter conventional threats, it is also capable of carrying out maritime security operations to ensure the safety and security of Singapore's waters, as well as various types of operations other than war (OOTW) such as humanitarian assistance and disaster relief (HADR) and peace support operations (PSO). The navy's capabilities can be classified into three main areas: strike, maritime security, and sealift. When mixed, these capabilities come together to enable the navy to fulfil a wide range of missions.

The strike role refers to the 'sharp end' of the navy's capabilities. It provides deterrence against any potential aggressor, and should deterrence fail enables the navy to quickly and effectively eliminate threats, be they underwater, on the sea surface, or in the air. The principal strike craft are the missile corvettes (MCVs) and the Formidable-class frigates equipped with Harpoon surface-to-surface missiles (SSMs). Besides surface combatants, the Maritime Patrol Aircraft also are equipped with the Harpoon missile and 
support the surface combatants in the surveillance role. As well, the Sikorsky S-70B naval helicopters operate off the Formidable-class frigates to provide task groups (TGs) at sea with an organic surveillance capability. Once operational, ship-launched unmanned aerial vehicles (UAVs) and unmanned surface vessels (USVs) will contribute significantly towards building an accurate picture of the seas around the TGs. The fighter aircraft of the Republic of Singapore Air Force also possess significant anti-ship strike capabilities.

The surface combatants have a significant anti-air capability with the Barak antimissile missile (AMM) onboard the MCVs and the Aster surface-to-air (SAM) on the Formidable-class frigates, the latter coupled with the frigate's multi-function radar (MFR) to provide an area air defence capability.

The anti-submarine capability on the surface combatants comes in the form of the variable depth sonars and lightweight torpedoes onboard the MCVs and the S-70B naval helicopters on the frigates which are equipped with dipping sonars, sonobuoys and torpedoes. The RSN's underwater capabilities took a major step forward with the acquisition of four Challenger-class submarines equipped with wire-guided heavyweight torpedoes in the 1990s. The submarine force recently was augmented when two Archerclass (improved Swedish Västergötland-class) submarines joined the fleet in 2010.

Singapore's SLOCs are its economic lifelines and hence maritime security is of vital importance to ensure that its waters are safe and its ports accessible. The Maritime Security Task Force (MSTF) is responsible for all operations within the Singapore Strait and other approaches to Singapore. It maintains a close watch of all that is happening within the Strait by working closely with the Police Coast Guard and the Maritime and Port Authority. The MSTF deploys its patrol vessels (PVs) to deal with any threat that may arise within the Singapore Strait. These are ships tasked with carrying out operational patrols and are deployed around the clock. The PVs perform numerous security tasks such as protection of vital shipping, anti-sea robbery and anti-illegal immigrant operations.

The presence of underwater mines is another major threat to the waterways and these explosives could easily cripple traffic in the Strait and severely impact Singapore's economic well-being. The navy's ability to deal with this underwater menace was bolstered with the acquisition of four Bedok-class mine countermeasure vessels (MCMVs). Complementing the MCMVs in mine disposal are the explosive ordnance disposal (EOD) divers from the Naval Diving Unit (NDU). Originally set up to support underwater repair and salvage operations, NDU has grown into a full-fledged formation. Today, it has built up a wide range of capabilities including salvage diving, explosive ordnance disposal, force protection, and ship boarding, as well as other combat diving operations. They play a vital role in maritime security.

Besides ensuring the security of the Singapore Strait, the navy also needs to ensure that its home bases are 'hardened' against terrorist attacks. This is the job of its Sea Soldiers, who are adept at base security operations both on land and at sea. On land, their job includes surveillance and security screening of people and vehicles entering the naval bases as well as patrolling the naval bases. At sea, they are well trained to conduct 
vessel detection and interception.

In addition to strike and maritime security, the navy has the ability to conduct sealift, transporting personnel and equipment across the sea. This is necessary not only to support the overseas training needs of the Singapore Armed Forces (SAF), but also to ensure that materiel and critical cargo can be transported to Singapore in times of need. This capability has also allowed the navy to respond to a number of HADR and PSO situations. The Endurance-class LSTs remain the navy's primary sealift assets. Augmenting them are a range of civil resource vessels, which can be deployed for sealift and transportation duties.

\section{Transformation - A Continuous Journey}

Transformation is not a destination; it is a journey. Since its early days, the navy has been on a journey of continual change and transformation. The pace of change picked up in the 1980s when the role of the navy started to move beyond constabulary duties. In the area of warfighting there has been acquisition of new technologies and the development of new doctrines and tactics. Organisationally, the navy has evolved, renewed and re-balanced its structure to meet expanding operational needs, constantly preparing and transforming its people for the challenges ahead. It continues to transform because it sees the future as an ever-shifting horizon, where the only constant is change and preparation for change.

The twin pillars of the navy's war-fighting transformation are the harnessing of technology and experimentation. These enable the development of unique and forwardlooking war-fighting concepts.

Being a small navy, the RSN had to develop its operating concepts based on the need to fight and win against a force that might be numerically superior. Thus, it has had to use technology as a force multiplier, starting with the Gabriel missile and investments in electronic warfare. By the mid-1980s, the navy had gained enough experience to undertake complex systems integration, including the integration of the Barak missile then an untested system - with the rest of the missile corvettes' combat systems.

Many of the technologies employed in the navy are developed locally through a close working relationship with partners such as DSO National Laboratories and DSTA. Today, harnessing of technology for war-fighting transformation is primarily aimed at increasing operational awareness and improving war-fighting superiority. Increased operational awareness will allow navy units at sea to obtain a better appreciation of the battlespace around them. navy ships will then be better able to detect, identify and engage enemy targets. Improved war-fighting superiority through the application of secret edge technologies and advanced combat systems will give the edge against any potential foe, anytime, anywhere.

The RSN has also invested heavily in decision support tools. For example, the frigate's state-of-the-art Combat Management System houses several intelligent engines for data fusion, track identification and threat evaluation. These serve to cut down routine operator tasks and help the frigate size up the battlespace much more efficiently 
and effectively. Examples of other transformational technologies being introduced include unmanned systems and the SAF's integrated knowledge-based command and control (IKC2) system.

Unmanned systems have started to play an important role in the modern battlefield. They give commanders a significantly greater awareness of the situation by collecting intelligence and can be employed in operations without putting servicemen in harm's way.

The RSN was possibly one of the first few navies in the world to deploy USVs for actual operations. During the three-month long deployment of RSS Resolution to the northern Persian Gulf in 2004, the Protector USV was used to assist in protecting critical infrastructure from terrorist attacks. The fishing dhows or traditional boats transiting the waters of the northern Gulf were quite surprised to be intercepted by a craft with no one on board. They duly complied with the instructions issued by this mystery boat. USV technology is still relatively new, and employment of such craft for security operations in an operational environment was quite novel and also generated interest among the coalition forces.

Looking ahead, the navy is experimenting with different types of unmanned systems for various tasks. UAVs and USVs can be used for maritime surveillance, interception and force protection, while unmanned underwater vehicle (UUV) systems can further expand capabilities in the underwater dimension.

Integrated knowledge-based command and control (IKC2) is a new operating paradigm that aims to harness the power of intelligent networking as a force multiplier. IKC2 networks the SAF and RSN's sensors, 'shooters' and communication nets across the entire battlespace. With IKC2, every combat system on every platform, as well as shore command and control systems, can work together as part of an integrated force that aims to "see first, understand first, decide first, and strike first." The RSN is transforming itself to become an integral part of the larger SAF-wide IKC2 network, one in which all three services will work seamlessly as one.

The culture of experimentation runs deep in the navy. Besides acquiring new platforms and systems, it has spent considerable time and effort undertaking trials on its equipment to ascertain their capability envelope. These have allowed the navy to tailor and optimize its weapons systems to fit its unique requirements. For example, starting from the 1980s, extensive testing and firing of Gabriel missiles have allowed the navy to fine-tune its Gabriel engagement criteria, to ensure an almost 100 percent hit probability against intended targets in the congested littoral environment. It has also enabled the navy to devise operating concepts and doctrines to meet specific operating scenarios.

Beyond its shores, the navy participates in collaborative experimentation programmes with other countries such as the United States, France and Sweden. This includes joint development of unmanned systems under the USN's Advanced Concept Technology Demonstration (ACTD) initiative, and exchanges on platform signature management with its counterparts from France. These experiments help the RSN redefine and transform its operating concepts to give it an added war-fighting edge. 


\section{Organisational Transformation}

The navy's organizational structure has changed significantly over the years. Formations within the RSN have undergone periodic restructuring and re-balancing to ensure their continued relevance to the SAF.

The navy set up the Naval Underwater Warfare Centre in 2001 and the Naval Surface Warfare Centre in 2004. Warfare centres (WARCENs) enable the RSN to reap cross-boundary synergies and to bring about greater integration between the operations, intelligence, logistics, plans and technology communities. This was the navy's form of 'hubbing' to bring together expertise from the plans, logistics and intelligence communities. Such an arrangement enables a more holistic approach towards capability development from the identification and specification of requirements, right up to bringing new capabilities into operation. The WARCENs also act as knowledge repositories for the various combat systems of the navy, ensuring that the rich experience and lessons painstakingly learnt over the years are captured, stored and disseminated.

Cross-boundary hubbing within the RSN is not confined to the WARCENs. In the mid-1990s, the introduction of new assets and the procurement of new capabilities created a need to develop new tactics and doctrines to maximize their new capabilities. A number of Flotilla Warfare Working Groups (FWWGs) were created in the 1990s to meet this need. FWWGs comprised flotilla staff, shipboard officers, representatives from the DSTA, DSO National Laboratories, naval logistics, and plans communities. These groups are instrumental in doctrine and tactics development, the conduct of trials and experiments, and the tracking of combat systems effectiveness. Cross-service working groups have also been formed to harness joint synergies.

\section{People Transformation}

The RSN firmly believes that the key to unlocking its full transformation potential lies in its people. To get the most out of advanced equipment, the RSN needs to elicit the best from its specialists and officers who maintain and operate the hardware. Each and every serviceman and servicewoman matters. The navy has therefore embarked on initiatives to transform its people to prepare them for future challenges.

Today, the navy is dealing with equipment and concepts that are at the very cutting edge. There are few signposts out there to follow. The navy needs to sail in uncharted waters, 'sensemake' and innovate. It needs to experiment, test out new ideas, and continually refine and adjust them so as to develop concepts that are imaginative and well tailored to its operating environments and requirements.

Information and knowledge are pivotal force multipliers in the modern battlespace. The ability to learn, share and create knowledge across the RSN and SAF are critical success factors in the navy's transformation journey hereon. Knowledge and intellectual capital residing in the members of the Navy Family are the RSN's main sources of competitive edge.

To prepare its men and women for this change, the navy has implemented a number of knowledge management (KM) initiatives. This includes teaching KM 
methodologies in the classroom, encouraging innovation and creativity in the workplace, and implementing technologies to enable a knowledge environment.

The navy's warrant officers, specialists and ratings (WOSRs) of the early years were occupied essentially with seamanship and basic operator work. Today, they are vested with the heavy responsibility of being the navy's experts in their respective fields. The navy has always believed in the tremendous potential of its WOSRs. Over the years, it has systematically empowered them and enlarged their contributions.

One milestone initiative was the CIC Supervisor - a senior WOSR charged with the smooth running of the ship's combat information centre (CIC). Another initiative underway is the creation of warfare supervisor roles onboard the frigates, where the WOSRs are empowered to supervise various clusters of systems. This frees up the officers to take a step back and fight the battle at the task group level.

\section{Conclusion}

In conclusion, from humble beginnings, the navy overcame daunting challenges, and from a crisis of confidence, it managed to redefine its strategic role. With the need to protect Singapore's SLOCs, the navy has steadily grown its ability to carry out a wide range of missions from peace to war, and in slightly over two decades from the 1990s to the 2000s the RSN has transformed into a balanced navy.

The Republic of Singapore Navy today is an effective operational force, capable of fulfilling a wide spectrum of missions to secure and advance Singapore's national interests. The balanced and capable navy of today has been realized through careful planning, far-sighted visioning and meticulous execution, as well as through the hard work and sheer grit of every man and woman in the RSN. 